\title{
Exogenous niacin treatment increases NADPH oxidase in kiwifruit
}

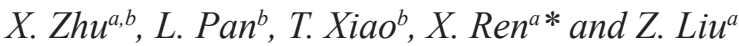 \\ ${ }^{a}$ College of Horticulture, Northwest A\&F University, Yangling, 712100, Shaanxi, China \\ ${ }^{b}$ Institute of Economic Crop Research, Shiyan Academy of Agricultural Sciences, Shiyan, 442714, Hubei, China \\ *e-mail: renxl@nwsuaf.edu.cn
}

Received: December 19, 2016 - Accepted: May 27, 2017 - Distributed: November 30, 2018

(With 5 figures)

\begin{abstract}
Kiwifruit are a popular fruit worldwide; however, plant growth is threatened by abiotic stresses such as drought and high temperatures. Niacin treatment in plants has been shown to increase NADPH levels, thus enhancing abiotic stresses tolerance. Here, we evaluate the effect of niacin solution spray treatment on NADPH levels in the kiwifruit cultivars Hayward and Xuxiang. We found that spray treatment with niacin solution promoted NADPH and NADP ${ }^{+}$levels and decreased both $\mathrm{O}_{2}$ - production and $\mathrm{H}_{2} \mathrm{O}_{2}$ contents in leaves during a short period. In fruit, NADPH contents increased during early development, but decreased later. However, no effect on $\mathrm{NADP}^{+}$levels has been observed throughout fruit development. In summary, this report suggests that niacin may be used to increase NADPH oxidases, thus increasing stress-tolerance in kiwifruit during encounter of short-term stressful conditions.
\end{abstract}

Keywords: $\mathrm{NADP}^{+}, \mathrm{H}_{2} \mathrm{O}_{2}$, niacin, Hayward, Xuxiang, $\mathrm{O}_{2}$.

\section{O tratamento com niacina exógena NADPH oxidase em kiwis}

\section{Resumo}

Kiwis são uma fruta popular em todo o mundo; No entanto, o crescimento das plantas é ameaçado por estresses abióticos como a seca e as altas temperaturas. O tratamento com niacina em plantas mostrou aumentar os níveis de NADPH, aumentando assim a tolerância a stress abiótico. Aqui, avaliamos o efeito do tratamento com spray de solução de niacina sobre os níveis de NADPH nos cultivares de kiwis Hayward e Xuxiang. Descobrimos que o tratamento por spray com solução de niacina promoveu níveis de NADPH e NADP + e diminuiu a produção de $\mathrm{O}_{2}{ }^{-}$e os teores de $\mathrm{H}_{2} \mathrm{O}_{2}$ nas folhas durante um curto período. Nos frutos, os teores de NADPH aumentaram durante o desenvolvimento precoce, mas diminuíram mais tarde. No entanto, não se observou qualquer efeito nos níveis de NADP + ao longo do desenvolvimento do fruto. Em resumo, este relatório sugere que a niacina pode ser utilizada para aumentar NADPH oxidases, aumentando assim a tolerância ao estresse em kiwis durante o encontro de condições estressantes de curto prazo.

Palavras-chave: $\mathrm{NADP}^{+}, \mathrm{H}_{2} \mathrm{O}_{2}$, niacina, Hayward, Xuxiang, $\mathrm{O}_{2}$ -

\section{Introduction}

The cycling of NADPH/NADP ${ }^{+}$plays a central role in the basal metabolism of all organisms. NADPH acts as a coenzyme and participates in the metabolism of sugars, fats, and proteins. NADPH is produced via reduction of $\mathrm{NADP}^{+}$, which is mainly produced via phosphorylation of $\mathrm{NAD}^{+}$(Lee et al., 2010). NADPH metabolite levels not only influence growth, but also play a central role in the antioxidant defense of plants (Fan et al., 2014; Hauben et al., 2009; Wallstrom et al., 2014). NADPH dehydrogenase affects vegetative growth, while NADPH oxidase has been reported to increase both immunity and plant cell growth (Foreman et al., 2003; Hao et al., 2006; Li et al., 2014a; Pourrut et al., 2008; Sagi et al., 2004; Wallstrom et al., 2014; Zhang et al., 2014). NADPH oxidase-based changes in physiology occur through the interaction of $\mathrm{NADPH}$ with $\mathrm{O}_{2}^{-}$, thus forming $\mathrm{H}_{2} \mathrm{O}_{2}$, and this resulting $\mathrm{H}_{2} \mathrm{O}_{2}$ regulates the expression of genes that alleviate stress (Orozco-Cardenas et al., 2001). NADPH oxidases are localized to the plasma-membrane, and are activated by high NADPH levels in the leaf vein (Shen et al., 2015). To take advantage of the oxidase abilities of NADPH to boost the plant immune system, extensive research has been conducted to obtain a variety of methods to increase NADPH concentration (Poulsen et al., 2005; Panagiotou et al., 2009; Piotrovskii et al., 2011).

Two common methods used to boost NADPH levels are to expose plants to particularly high light-intensity, or to metabolically engineer a way to increase the NADPH concentration in plants (Lee et al., 2010; Quiles and López, 2004). However, these methods have not been successful in the kiwifruit, which is an important fruit crop. Actinidia deliciosa (kiwifruit) is an important export fruit that has high vitamin 
C content; however, cultivating kiwifruit can be difficult due to the plant's particularly high sensitivity to stress (drought, flood, and high temperature). One potential avenue to increase kiwifruit yield, while decreasing crop damage would be to boost NADPH oxidase activity, thus increasing in the immunity of kiwifruit, while reducing stress. Previous work has increased the NADPH content in Aspergillus niger, using transgenic alteration of metabolic pathways; however, this is not suitable for already established kiwifruit orchards (Poulsen et al., 2005). Established kiwifruit orchards require a valid method that allows for short-term adaptation to stress. The Hayward kiwifruit cultivar is the most widely planted kiwifruit in the world and the Xuxiang cultivar is a widely planted cultivar throughout China; both are threatened by adverse environmental conditions, for which increasing the NADPH content offers a remedy.

Niacin (vitamin $\mathrm{B}_{3}$ ) acts as a coenzyme and plays a role in the metabolic hydrogen transfer to $\mathrm{NADP}^{+}$as nicotinamide via ATP. Proper concentrations of niacin treatment in Tripterygium wilfordii and Ginkgo biloga L promoted growth, which has also been reported for Coprinus comatu (Jiang et al., 1999; Wang and Bai, 2014; Li et al., 2014b). Spraying niacin on kiwifruit plants may increase NADPH content, thus increasing NADPH oxidase activity. Here, we treated kiwifruit by spraying $1 \mathrm{mg} / \mathrm{L}$ of niacin and measured the resulting NADPH levels in plants. We observed changes in both Hayward and Xuxiang cultivars, and the results suggest that spraying kiwifruit with niacin may provde an effective short-term solution to remedy stress in kiwifruit.

\section{Material and Methods}

\subsection{Chemical reagents}

All reagents were obtained from Solarbio (Beijing, China), except for Glucose-6-phosphate dehydrogenase (G6PDH), which was obtained from Sigma (St. Louis, MO).

\subsection{Plant materials and treatment}

Two 10-year-old kiwifruit cultivars (Hayward and Xuxiang) were acquired from the Kiwifruit Experimental Station of the Northwest Agricultural and Forestry University in Shaanxi Province, China. To ensure consistency of the experiment, we used 10 individuals from each cultivar in the same field. $1 \mathrm{mg} / \mathrm{L}$ niacin was sprayed onto the kiwifruit (including leaves and young fruits) at 4:00 PM during the flowering period. Un-sprayed Hayward and Xuxiang plants were used as control. Each treatment was repeated five times.

The first sampling was conducted 16 hours after niacin spraying. Other sampling times took place every two weeks until the fruits were ready for harvest. Each sampling consisted of five leaves and five fruits per plant.

\subsection{Measurement of the chlorophyll content}

For the measurement of the chlorophyll content, leaves $(0.2 \mathrm{~g})$ were homogenized in $10 \mathrm{~mL}$ of $80 \%$ acetone until the leaves turned white, before the samples were filtered through filter paper. The filtrate was tested on a UV spectrophotometer (UV-1800, Shimadzu, Japan) at wavelengths of $663 \mathrm{~nm}$ and $645 \mathrm{~nm}$. Each test was repeated thrice per sample.

\subsection{Measurement of $N A D P+$ and NADPH}

The NADP ${ }^{+}$and NADPH levels were quantified via enzymatic cycling, using the phenazine methosulfate (PMS)-catalyzed reduction thiazolyl blue (MTT) method in the presence of glucose 6-phosphate (G6P) for $\mathrm{NADP}^{+}$, and glucose 6-phosphate dehydrogenase (G6PDH) for NADPH. MTT reduction to formazan was conducted according to a previously described method (Queval and Noctor, 2007). First, leaves and fruits (1 g) were homogenized in $4 \mathrm{~mL}$ of $0.04 \mathrm{M} \mathrm{NaOH}$, and the extract was centrifuged at $12,000 \mathrm{~g}$ for $10 \mathrm{~min}$ at $4{ }^{\circ} \mathrm{C}$. To determine NADPH levels, $400 \mu \mathrm{L}$ of neutralized supernatant was introduced into plate wells, containing $0.4 \mathrm{~mL}$ of $0.04 \mathrm{M} \mathrm{NaOH}$, $100 \mu \mathrm{L} 5 \mathrm{mM}$ EDTA, $10 \mu \mathrm{L}$ of $2 \mathrm{mM}$ PMS, and $30 \mu \mathrm{L}$ of water, as well as $10 \mu \mathrm{L}$ additional G6PDH $\left(200 \mathrm{U} \mathrm{ml}^{-1}\right)$ for NADPH only. When determining the amounts of $\mathrm{NADP}^{+}$, $0.4 \mathrm{~mL} 0.01 \mathrm{M} \mathrm{H}_{2} \mathrm{SO}_{4}$ and $0.1 \mathrm{M} \mathrm{Na}_{2} \mathrm{SO}_{4}$ were used instead of $\mathrm{NaOH}$, and the remaining conditions were identical to those used for the NADPH measurement. Following automatic mixing via shaking and heating at $60{ }^{\circ} \mathrm{C}$ for 30 minutes, $10 \mu \mathrm{L}$ of $10 \mathrm{mM}$ G6P was added, then analyzed with a UV spectrophotometer (UV-1800, SHIMADZU, Kyoto, Japan) at a wavelength of $570 \mathrm{~nm}$. The NADPH content was calculated via reference to standards that were run concurrently, and expressed as milligrams per gram fresh weight (FW). Analysis of each sample was repeated thrice.

\subsection{Determination of $\mathrm{H}_{2} \mathrm{O}_{2}$ content and $\mathrm{O}_{2}$ production rate in kiwifruit}

The $\mathrm{H}_{2} \mathrm{O}_{2}$ content was measured using $0.2 \mathrm{~g}$ of leaves and $1 \mathrm{~g}$ of kiwifruit exact. The extract was supplemented with acetone to a volume of $4 \mathrm{~mL}$ and centrifuged for $10 \mathrm{~min}$ at $12000 \mathrm{~g}$. The supernatant $(1 \mathrm{~mL})$ was mixed with an equal volume of $0.1 \mathrm{M} \mathrm{TiCl}_{4}$ in $20 \% \mathrm{HCl}$ and then, $200 \mu \mathrm{L}$ of concentrated aqueous $\mathrm{NH}_{4} \mathrm{OH}$ were added to precipitate the titanium-peroxide complex. This solution was centrifuged at $3000 \mathrm{~g}$ for $5 \mathrm{~min}$ and the precipitate was washed thrice with cold acetone to remove pigments. The sample was then dissolved in $3 \mathrm{~mL}$ of $1 \mathrm{M} \mathrm{H}_{2} \mathrm{SO}_{4}$, and measured at a wavelength of $415 \mathrm{~nm}$ (Piotrovskii et al., 2011). The rate of $\mathrm{O}_{2}$ - production was measured by monitoring the formation of nitrite from hydroxylamine with $\mathrm{O}_{2}{ }^{-}$(Jiang and Zhang, 2001).

\subsection{Statistical analysis}

Excel 2010 and Sigma Plot 12.0 were employed for statistical data analysis. Data were tested via analysis of variance (ANOVA) using SPSS statistics 20.0, and the means were compared with the least significant difference (LSD) test. One-way ANOVA was used to assess differences. $P$-values below 0.05 were considered significant $(P<0.05)$. All measured values are presented as mean \pm standard deviation (SD)

\section{Results}

To test whether niacin-treatment can increase the stress-response in two common kiwifruit cultivars, we sprayed kiwifruits with niacin and first tested chlorophyll 
content in the leaves. Interestingly, although the chlorophyll content increased in both cultivars, the timing was different. The Hayward cultivar had a higher chlorophyll content than the control (3.09 mg/g FW) when plants were treated during the second stage, and the Xuxiang cultivar $(3.15 \mathrm{mg} / \mathrm{g} \mathrm{FW})$ had a higher chlorophyll content than control for most times; no significant differences were found, except at the first stage of Xuxiang $(\mathrm{P}<0.05)$ (Figures 1A, B).

We next tested levels of NADPH/NADP ${ }^{+}$in niacin-treated plants in comparison to untreated plants. Niacin-treated plants showed a change in $\mathrm{NADP}^{+}$levels in young fruit, while controls showed no such change (Figures 2C, D). The NADP ${ }^{+}$content in both the Hayward and Xuxiang cultivars increased rapidly during some stages upon niacin treatment in leaves. In treated plants leaves, the Hayward cultivar had $300 \%$ higher $\mathrm{NADP}^{+}$levels after two treatment periods, while the Xuxiang cultivar had $54 \%$ higher $\mathrm{NADP}^{+}$levels after four treatment periods (Figures 2A, B). For example, $\mathrm{NADP}^{+}$levels increased from $1.93 \mathrm{nmol} / \mathrm{g}$ to $12.6 \mathrm{nmol} / \mathrm{g}$ in the Hayward cultivar, and from $0.66 \mathrm{nmol} / \mathrm{g}$ to $2.89 \mathrm{nmol} / \mathrm{g}$ in the Xuxiang cultivar (Figures 2A, B).

Fruits treated with niacin often had higher NADPH-levels compared to controls (Figures 3C, D). The NADPH content in leaves of the Hayward cultivar increased sharply during the second stage, and the NADPH content in leaves of the Xuxiang cultivar increased during the fourth stage (Figures 3A, B). We found that after spraying with niacin, both cultivars had two spikes in NADPH levels of fruits, and the Hayward cultivar had higher NADPH-levels during the first peak, while the Xuxiang cultivar had higher NADPH-levels during the second peak. The NADPH content showed a similar trend with peaks in NADPH-levels in both treatments and control; however, the peaks occurred earlier in plants that were treated with niacin (Figures 3A, B). We observed a significant increase in NADPH content from $15 \mathrm{nmol} / \mathrm{g}$ to $117 \mathrm{nmol} / \mathrm{g}$ in the Hayward cultivar after two periods (Figure 3A), and from $16.2 \mathrm{nmol} / \mathrm{g}$ to $39 \mathrm{nmol} / \mathrm{g}$ in the Xuxiang cultivar after four periods (Figure 3B). Figure 3 shows that most measurements revealed significant differences between treatment and control $(\mathrm{P}<0.05)$.

Lastly, we tested for $\mathrm{O}_{2}{ }^{-}$and $\mathrm{H}_{2} \mathrm{O}_{2}$ contents in plants, both of which are indicators of NADPH oxidase activity. We found that plants that had been treated with niacin had increased $\mathrm{O}_{2}^{-}$production in the leaves at first, but showed no further distinct differences in leaves or fruit over time $(\mathrm{P}<0.05)$ (Figures 4A-D). Interestingly, we found that most times the $\mathrm{H}_{2} \mathrm{O}_{2}$ content was lower in leaves of the treatment groups than in leaves of control (Figures 5A, B); however, no such phenomenon was found in Figure 4.
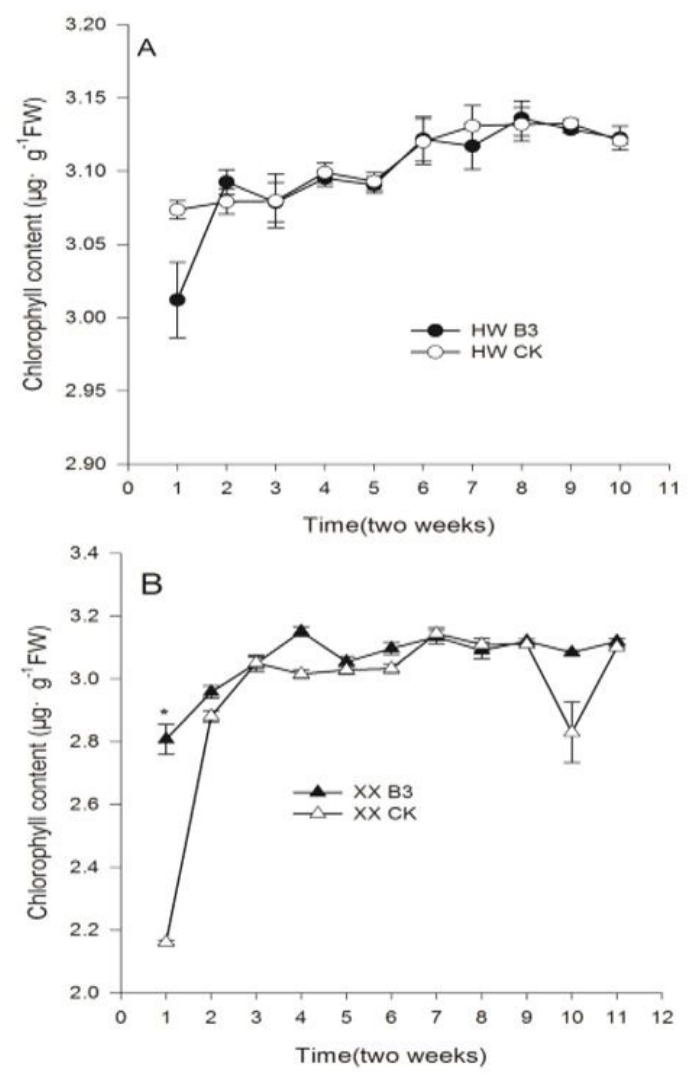

Figure 1. Changes of the chlorophyll content of Hayward and Xuxiang leaves after niacin treatment. Asterisk $(*)$ indicate significant differences between control and treatment in the same stage at 0.05 . 

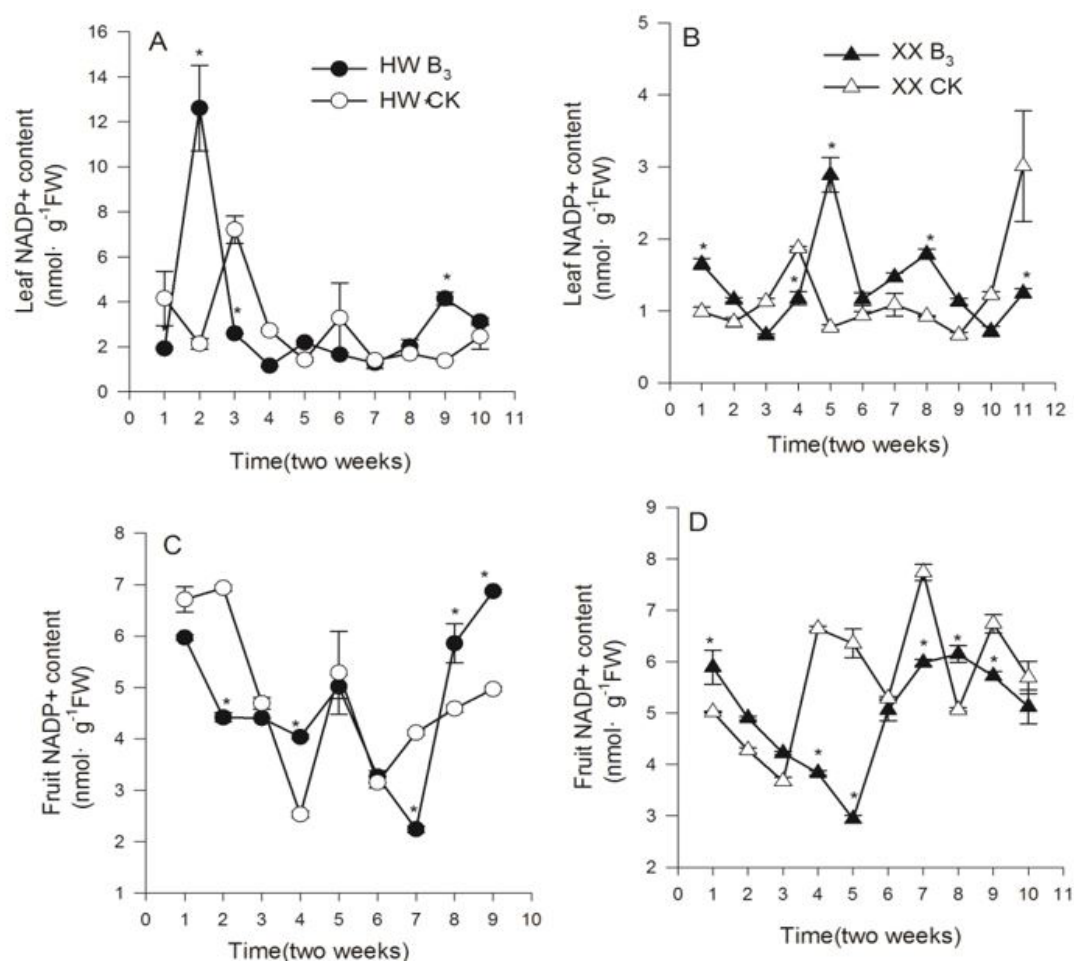

Figure 2. NADP+ content changes upon niacin treatment in Xuxiang cultivars. Asterisk $(*)$ indicate significant differences between control and treatment in the same stage at 0.05 .
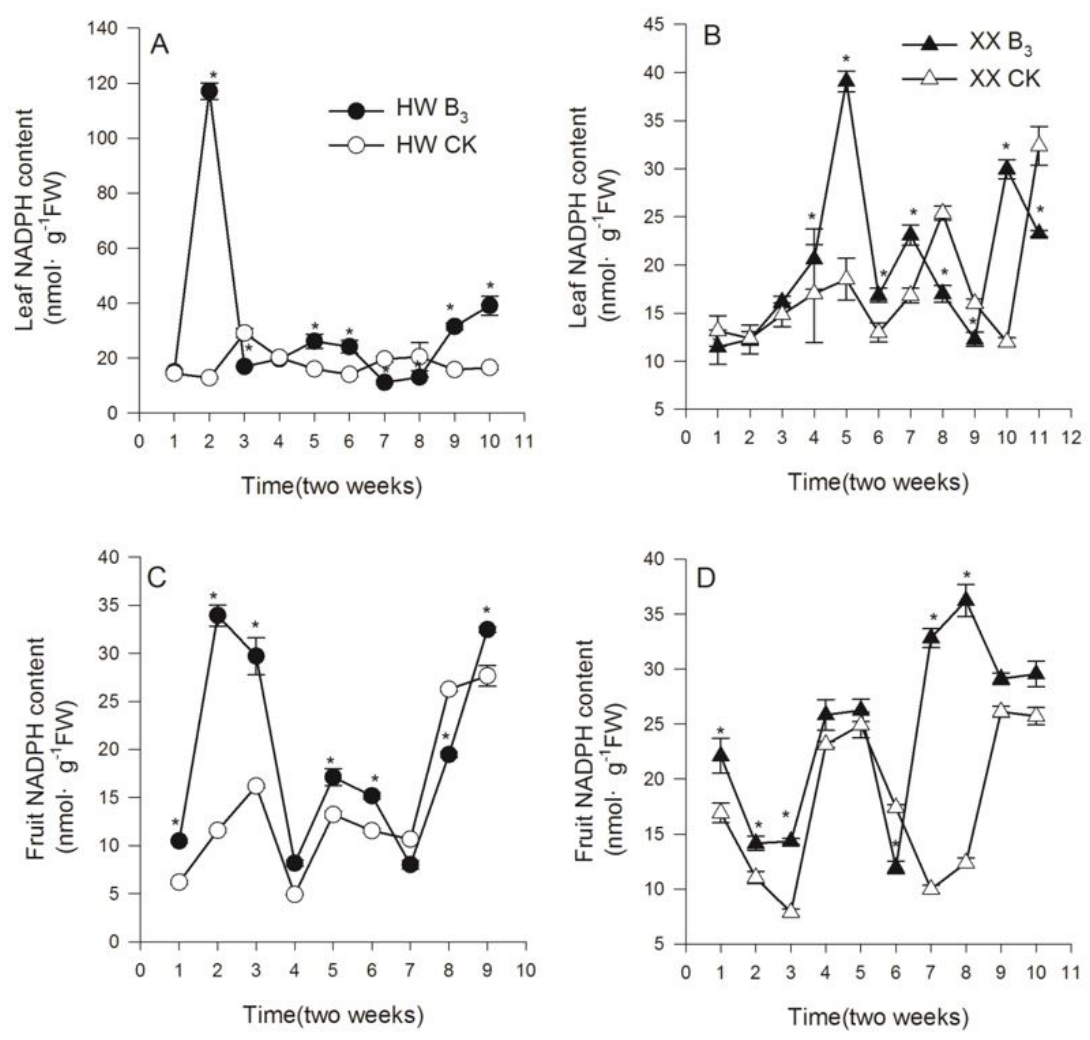

Figure 3. NADPH content changes in Hayward and Xuxiang cultivars upon niacin treatment. Asterisk(*) indicate significant differences between control and treatment in the same stage at 0.05 . 

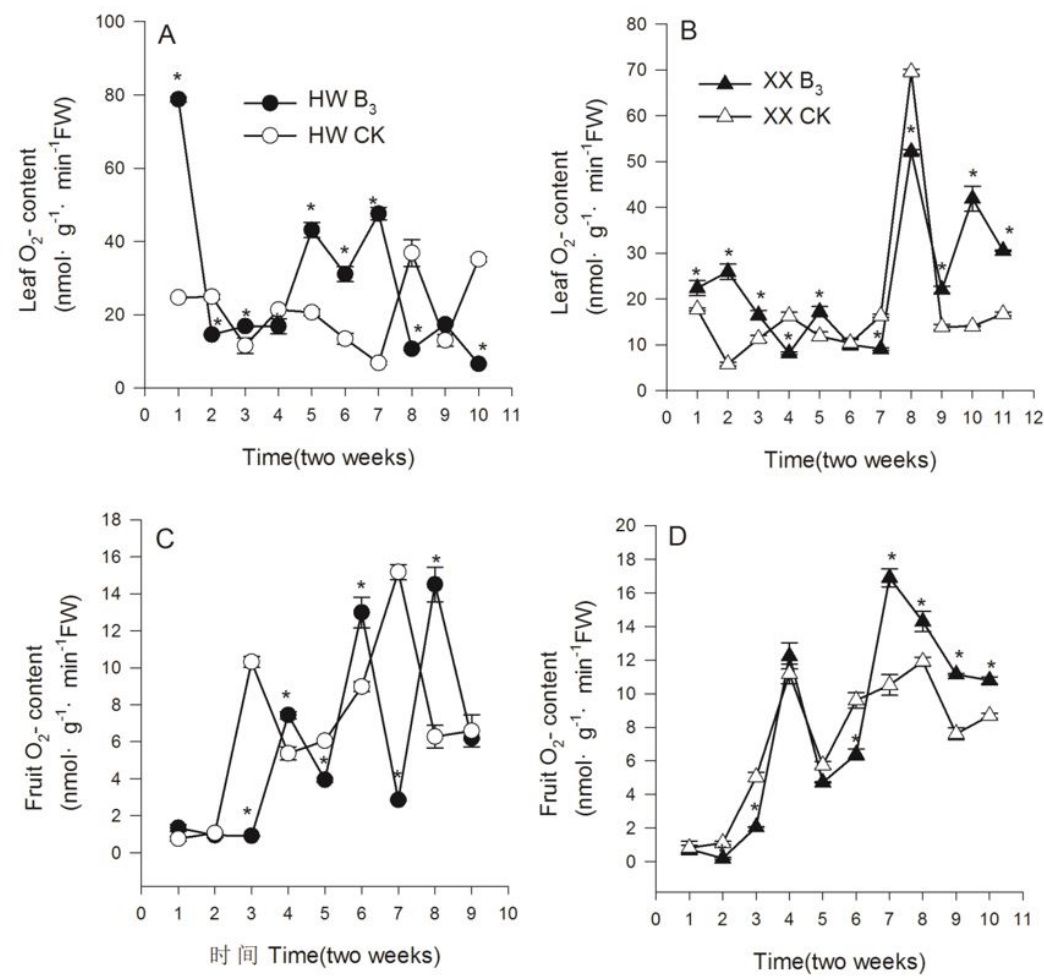

Figure 4. $\mathrm{O}_{2}^{-}$production is affected in leaves and fruits of kiwifruit treated with niacin. Asterisk(*) indicate significant differences between control and treatment in the same stage at 0.05 .
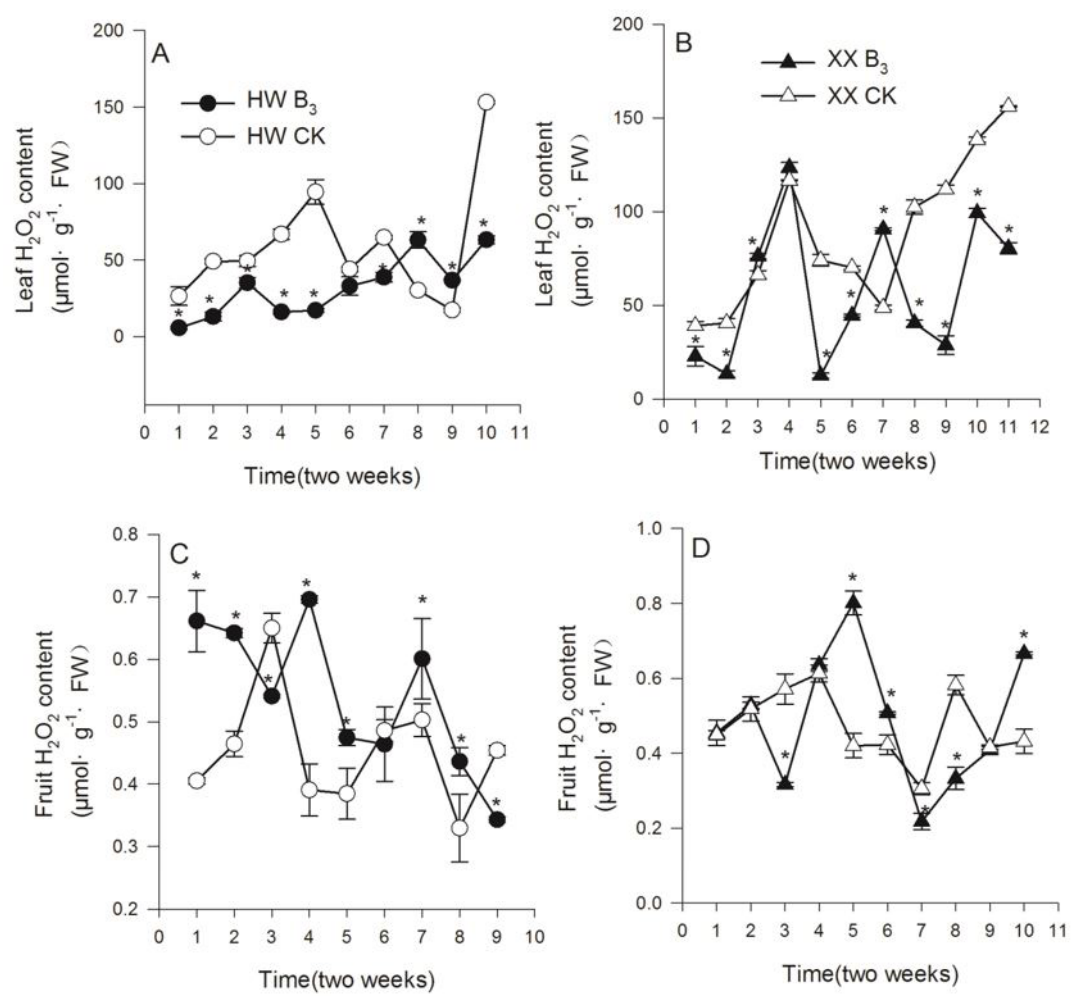

Figure 5. $\mathrm{H}_{2} \mathrm{O}_{2}$ content in kiwifruit leaves treated with niacin. Asterisk $(*)$ indicate significant differences between control and treatment in the same stage at 0.05 . 


\section{Discussion}

In this study, we found that the NADPH concentration increased both in leaves and young fruit of two different kiwifruit cultivars and subsequent to spraying with $1 \mathrm{mg} / \mathrm{L}$ niacin; however, the increases occurred at different times in both cultivars. The reason is that Hayward and Xuxiang cultivars flower at different times, and consequently undergo fruit development at different times. The increase in NADPH levels appeared to correspond to the fruit enlargement period, suggesting that niacin affected $\mathrm{NADP}^{+}$and NADPH contents during this time. When kiwifruit plants were sprayed with niacin, the chlorophyll content increased in leaves of both cultivars, albeit for a short period of time. This suggests that the treatment affected the chlorophyll content in a short period, and that chlorophyll content increased at first. In the Hayward cultivar, we observed a significant increase in the chlorophyll content during the first two periods, a rapid and significant increase in $\mathrm{NADP}^{+}$and NADPH content also during this stage. An increase of NADPH concentration was observed in the green algae (Chlamydomonas reinhardtii); however, the researcher used different reagents, and the observed difference might be caused by the particular way in which niacin treatment affects kiwifruits: first promoting chlorophyll synthesis and then increasing NADPH content in young fruits and leaves (White et al., 2014). This effect only affected the NADPH content, but not the NADP ${ }^{+}$, $\mathrm{NAD}^{+}$or NADH content (Figure 1S, Figure $2 \mathrm{~S}$ ), also had little influence on SOD content (Figure 3S); therefore, treatment with niacin was more beneficial for NADPH content in kiwifruits.

In fruit, we observed a significant difference in NADPH content compared to control in leaves and young fruits during early stages of spraying (Figure 3 ). When niacin was sprayed on kiwifruit during the blooming stage, it is possible that the leaves absorbed most of the niacin, and then transferred it to the fruit during later stages. Treated kiwifruit plants had a higher $\mathrm{NADP}^{+}$content than control plants. Young fruit and leaves are often composed of growing cells, which may have caused the different trends in $\mathrm{NADP}^{+} / \mathrm{NADPH}$ content in different parts and stages of the treated plants.

The NADPH content was higher than the $\mathrm{NADP}^{+}$content in leaves and fruit of both cultivars. $\mathrm{NADP}^{+}$is predominantly maintained in its reduced form, and this $\mathrm{NADP}^{+}$is used to promote NADPH production to further reduce oxidative tension (Singh et al., 2007). The NADPH/NAPD ${ }^{+}$content sometimes showed abrupt increases subsequent to niacin spraying, which is a precursor to $\mathrm{NAPD}^{+}$. $\mathrm{NADP}^{+}$content could promote NADPH content, thus further reducing oxidative tension (Singh et al., 2007). Therefore, in our study, the higher NADPH content may have resulted from the NAPD ${ }^{+}$consumption, leading to lower $\mathrm{NADP}^{+}$content. Previous research described that NADPH production increased in growing cells, but decreased during times of growth-inhibiting oxidative stress (Fan et al., 2014). We found that the NADPH content in leaves and young fruit increased during times of rapid growth, while it dropped during periods of slow growth. NADPH plays an equal role in redox defense and reductive biosynthesis, and when NADPH content increased, defense could enhance (Fan et al., 2014). Thus, the increasing NADPH content could increase kiwifruit stress defense.

We found that spraying niacin had the most effect on the $\mathrm{NADP}^{+} / \mathrm{NADPH}$ content in leaves for the Hayward cultivar during second stage, while it was the fourth stage for the Xuxiang cultivar. The Hayward cultivar had an increase in $\mathrm{NADP}^{+} / \mathrm{NADPH}$ in the first two periods, in contrast to the Xuxiang cultivar (where this increase was observed during the first four periods). These differences may have influenced the physiological activity related to NADPH in leaves and young fruit. The $\mathrm{NADP}^{+}$content was lower than the NADPH content in both cultivars; similar findings have been reported in the leaves of Brassica napus (Tewari et al., 2014). However, in kiwifruit leaves, we observed a content change over time due to the spraying of niacin.

Spraying with niacin promoted the production of $\mathrm{O}_{2} \cdots$; however, it did not have a long-term effect, thus after a relatively short period of time, the $\mathrm{O}_{2}$ - production levels returned to control levels. The $\mathrm{H}_{2} \mathrm{O}_{2}$ content was lower in treatment than in control, which is likely due to the kiwifruit's fast growth stage, thus protective enzymes such as superoxide dismutase (SOD) would have reduced the production of NADPH oxidase and kept it low in periods of normal growth (Shen et al., 2015). Increased NADPH content has also been shown to diminish oxidative tension (Diaz-Flores et al., 2006). For example, ABA increased NADPH oxidase production within 24 hours in short-term salinity stress in wheat roots (Hao et al., 2006; Jiang and Zhang, 2001; Yang et al., 2007). A transient increase has been reported for kiwifruit growth, which is similar to a temporal pattern in the production of ROS that was observed in Arabidopsis thaliana (Xie et al., 2014). Other researchers have used genetic methods to vary the status of NADPH in annual plants; however, in perennial plants transgenosis, this cannot become effective immediately (Wallstrom et al., 2014). Spraying niacin to promote NADPH content offers a feasible alternative for perennial plants.

\section{Conclusion}

$1 \mathrm{mg} / \mathrm{L}$ of niacin was sprayed on the leaves during the flowering of kiwifruit, it had a short-term increasing effect of chlorophyll content, $\mathrm{O}_{2}$ - production, and $\mathrm{H}_{2} \mathrm{O}_{2}$ content, and promoted $\mathrm{NADP}^{+}$and NADPH content in two kiwifruit cultivar leaves. In the fruit, niacin spray treatment enhanced the NADPH content in young fruit, but had a contrasting effect on the NADPH content in mature fruits, and with no apparent effect on the $\mathrm{NADP}^{+}$content. Our results show that treatment with niacin could increase the NADPH and NADPH oxidase contents in kiwifruit leaves, which may be used to enhance kiwifruit defense against stress. 


\section{Acknowledgements}

We thank the Kiwifruit Experimental Station of the Northwest Agricultural \& Forestry University for providing material assistance.

\section{References}

DÍAZ-FLORES, M., IBANEZ-HERNANDEZ, M.A., GALVAN, R.E., GUTIERREZ, M., DURAN-REYES, G., MEDINANAVARRO, R., PASCOE-LIRA, D., ORTEGA-CAMARILLO, C., VILAR-ROJAS, C., CRUZ, M. and BAIZA-GUTMAN, L.A., 2006. Glucose-6-phosphate dehydrogenase activity and $\mathrm{NADPH} / \mathrm{NADP}(+)$ ratio in liver and pancreas are dependent on the severity of hyperglycemia in rat.Life Sciences, vol. 78, no. 22, pp. 2601-2607. PMid:16325866.http://dx.doi.org/10.1016/j. lfs.2005.10.022

FAN, J., YE, J., KAMPHORST, J.J., SHLOMI, T., THOMPSON, C.B. and RABINOWITZ, J.D., 2014. Quantitative flux analysis reveals folate-dependent NADPH production.Nature, vol. 510, no. 7504, pp. 298-302. PMid:24805240.http://dx.doi.org/10.1038/ nature13236.

FOREMAN, J., DEMIDCHIK, V., BOTHWELL, J.H.F., MYLONA, P., MIEDEMA, H., TORRES, M.A., LINSTEAD, P., COSTA, S., BROWNLEE, C., JONES, J.D.G., DAVIES, J.M. and DOLAN, L., 2003. Reactive oxygen species produced by NADPH oxidase regulate plant cell growth.Nature, vol. 422, no. 6930, pp. 442-446. PMid:12660786.http://dx.doi.org/10.1038/nature01485.

HAO, F.S., WANG, X.C. and CHEN, J., 2006. Involvement of plasma-membrane NADPH oxidase in nickel-induced boxidative stress in roots of wheat seedlings.Plant Science, vol. 170, no. 1, pp. 151-158. http://dx.doi.org/10.1016/j.plantsci.2005.08.014.

HAUBEN, M., HAESENDONCKX, B., STANDAERT, E., VAN DER KELEN, K., AZMI, A., AKPO, H., VAN BREUSEGEM, F., GUISEZ, Y., BOTS, M., LAMBERT, B., LAGA, B. and DE BLOCK, M., 2009. Energy use efficiency is characterized by an epigenetic component that can be directed through artificial selection to increase yield.Proceedings of the National Academy of Sciences of the United States of America, vol. 106, no. 47, pp. 20109-20114. PMid:19897729.http://dx.doi.org/10.1073/ pnas.0908755106.

JIANG, L., ZHANG, W. and KE, Y., 1999. Effects of organic elements cell growth and formation of flavonol glycosides of Ginkgo gallus.Journal of Agricultural Biotechnology, vol. 7, no. 4, pp. 373-376.

JIANG, M.Y. and ZHANG, J.H., 2001. Effect of abscisic acid on active oxygen species, antioxidative defence system and oxidative damage in leaves of maize seedlings.Plant \& Cell Physiology, vol. 42, no. 11, pp. 1265-1273. PMid:11726712.http://dx.doi. org/10.1093/pcp/pce162.

LEE, H.C., KIM, J.S., JANG, W. and KIM, S.Y., 2010. High $\mathrm{NADPH} / \mathrm{NADP}+$ ratio improves thymidine production by a metabolically engineered Escherichia coli strain.Journal of Biotechnology, vol. 149, no. 1-2, pp. 24-32. PMid:20600382. http://dx.doi.org/10.1016/j.jbiotec.2010.06.011.

LI, L., LI, M., YU, L., ZHOU, Z., LIANG, X., LIU, Z., CAI, G., GAO, L., ZHANG, X., WANG, Y., CHEN, S. and ZHOU, J.M., 2014a. The FLS2-associated kinase BIK1 directly phosphorylates the NADPH oxidase RbohD to control plant immunity.Cell Host
\& Microbe, vol. 15, no. 3, pp. 329-338. PMid:24629339.http:// dx.doi.org/10.1016/j.chom.2014.02.009.

LI, Y., CUI, L., LEI, J.M., LI, Q. and ZHANG, X., 2014b. Effects of different concentrations of organic affixture on the growth and secondary metabolites contents in adventitious roots of Tripterygium willfordii.Plant Science Journal, vol. 32, no. 2, pp. 174-180.

OROZCO-CARDENAS, M.L., NARVAEZ-VASQUEZ, J. and RYAN, C.A., 2001. Hydrogen peroxide acts as a second messenger for the induction of defense genes in tomato plants in response to wounding, systemin, and methyl jasmonate.The Plant Cell, vol. 13, no. 1, pp. 179-191. PMid:11158538.http:// dx.doi.org/10.1105/tpc.13.1.179.

PANAGIOTOU, G., GROTKJAER, T., HOFMANN, G., BAPAT, P.M. and OLSSON, L., 2009. Overexpression of a novel endogenous NADH kinase in Aspergillus nidulans enhances growth.Metabolic Engineering, vol. 11, no. 1, pp. 31-39. PMid:18840540.http:// dx.doi.org/10.1016/j.ymben.2008.08.008.

PIOTROVSKII, M.S., SHEVYREVA, T.A., ZHESTKOVA, I.M. and TROFIMOVA, M.S., 2011. Activation of plasmalemmal NADPH oxidase in etiolated maize seedlings exposed to chilling temperatures.Russian Journal of Plant Physiology: a Comprehensive Russian Journal on Modern Phytophysiology, vol. 58, no. 2, pp. 290-298. http://dx.doi.org/10.1134/S1021443711020154.

POULSEN, B.R., NØHR, J., DOUTHWAITE, S., HANSEN, L.V., IVERSEN, J.J.L., VISSER, J. and RUIJTER, G.J.G., 2005. Increased NADPH concentration obtained by metabolic engineering of the pentose phosphate pathway in Aspergillus niger.The FEBS Journal, vol. 272, no. 6, pp. 1313-1325. PMid:15752350.http:// dx.doi.org/10.1111/j.1742-4658.2005.04554.x.

POURRUT, B., PERCHET, G., SILVESTRE, J., CECCHI, M., GUIRESSE, M. and PINELLI, E., 2008. Potential role of NADPHoxidase in early steps of lead-induced oxidative burst in Vicia faba roots.Journal of Plant Physiology, vol. 165, no. 6, pp. 571-579. PMid:17931743.http://dx.doi.org/10.1016/j.jplph.2007.07.016.

QUEVAL, G. and NOCTOR, G., 2007. A plate reader method for the measurement of NAD, NADP, glutathione, and ascorbate in tissue extracts: application to redox profiling during Arabidopsis rosette development.Analytical Biochemistry, vol. 363, no. 1, pp. 58-69. PMid:17288982.http://dx.doi.org/10.1016/j.ab.2007.01.005.

QUILES, M.A.J. and LÓPEZ, N.I., 2004. Photoinhibition of photosystems I and II induced by exposure to high light intensity during oat plant growth.Plant Science, vol. 166, no. 3, pp. 815823. http://dx.doi.org/10.1016/j.plantsci.2003.11.025.

SAGI, M., DAVYDOV, O., ORAZOVA, S., YESBERGENOVA, Z., OPHIR, R., STRATMANN, J.W. and FLUHR, R., 2004. Plant respiratory burst oxidase homologs impinge on wound responsiveness and development in Lycopersicon esculentum. The Plant Cell, vol. 16, no. 3, pp. 616-628. PMid:14973161. http://dx.doi.org/10.1105/tpc.019398.

SHEN, W., CHEN, G., XU, J., ZHEN, X., MA, J., ZHANG, X., LV, C. and GAO, Z., 2015. High light acclimation of Oryza sativa $\mathrm{L}$. leaves involves specific photosynthetic-sourced changes of NADPH/NADP $(+)$ in the midvein.Protoplasma, vol. 252, no. 1, pp. 77-87. PMid:24888399.http://dx.doi.org/10.1007/ s00709-014-0662-8.

SINGH, R., MAILLOUX, R.J., PUISEUX-DAO, S. and APPANNA, V.D., 2007. Oxidative stress evokes a metabolic adaptation that favors increased NADPH synthesis and decreased NADH production in Pseudomonas fluorescens.Journal of Bacteriology, 
vol. 189 , no. 18 , pp. 6665-6675. PMid:17573472.http://dx.doi. org/10.1128/JB.00555-07.

TEWARI, R.K., SATOH, M., KADO, S., MISHINA, K., ANMA, M., ENAMI, K., HANAOKA, M. and WATANABE, M., 2014. Overproduction of stromal ferredoxin:NADPH oxidoreductase in $\mathrm{H} 2 \mathrm{O}$ 2-accumulating Brassica napus leaf protoplasts.Plant Molecular Biology, vol. 86, no. 6, pp. 627-639. PMid:25255860. http://dx.doi.org/10.1007/s11103-014-0252-3.

WALLSTROM, S.V., FLOREZ-SARASA, I., ARAUJO, W.L., AIDEMARK, M., FERNANDEZ-FERNANDEZ, M., FERNIE, A.R., RIBAS-CARBO, M. and RASMUSSON, A.G., 2014. Suppression of the external mitochondrial NADPH dehydrogenase, NDB1, in Arabidopsis thaliana affects central metabolism and vegetative growth.Molecular Plant, vol. 7, no. 2, pp. 356-368. PMid:23939432.http://dx.doi.org/10.1093/mp/sst115.

WANG, X.Y. and BAI, X.Y., 2014. Effects of ethephon and nicotinic acid on mycelium and polysaccharide yield in Coprinus comatus of liquid culture.Hubei Agricultural Sciences, vol. 53, no. 6 , pp. $1349-1351$.
WHITE, S., ANANDRAJ, A. and TROIS, C., 2014. NADPH fluorescence as an indicator of hydrogen production in the green algae Chlamydomonas reinhardtii.International Journal of Hydrogen Energy, vol. 39, no. 4, pp. 1640-1647. http://dx.doi. org/10.1016/j.ijhydene.2013.11.016.

XIE, H.T., WAN, Z.Y., LI, S. and ZHANG, Y., 2014. Spatiotemporal production of reactive oxygen species by NADPH oxidase is critical for tapetal programmed cell death and pollen development in arabidopsis.The Plant Cell, vol. 26, no. 5, pp. 2007-2023. PMid:24808050.http://dx.doi.org/10.1105/tpc.114.125427.

YANG, Y., XU, S., AN, L. and CHEN, N., 2007. NADPH oxidasedependent hydrogen peroxide production, induced by salinity stress, may be involved in the regulation of total calcium in roots of wheat.Journal of Plant Physiology, vol. 164, no. 11, pp. 1429-1435. PMid:17223222.http://dx.doi.org/10.1016/j.jplph.2006.08.009.

ZHANG, J., CHEN, C., ZHANG, D., LI, H., LI, P. and MA, F., 2014. Reactive oxygen species produced via plasma membrane NADPH oxidase regulate anthocyanin synthesis in apple peel. Planta, vol. 240, no. 5, pp. 1023-1035. PMid:25000919.http:// dx.doi.org/10.1007/s00425-014-2120-4. 
Zhu, X. et al.

\section{Supplementary material}

Supplementary material accompanies this paper.

Figure 1S. NAD+ content in leaves and fruit of kiwifruit after niacin treatment.

Figure 2S. NADH content in leaves and fruit of kiwifruit after niacin treatment.

Figure 3S. Superoxide dismutase content in leaves and fruit of kiwifruit after niacin treatment.

This material is available as part of the online article from http://www.scielo.br/bjb. 